The North American Conference on British Studies announces the winners of its 1993 prizes for scholarship.

The British Council Prize in the Humanities for the best book of 1992 in any field of British Studies has been awarded to

\author{
Richard Helgerson \\ for his book \\ Forms of Nationhood: The Elizabethan Writing of England \\ University of Chicago Press, 1992
}

The John Ben Snow Prize for the best book of 1992 in History and the Social Sciences has been awarded to

$$
\begin{aligned}
& \text { David Underdown } \\
& \text { for his book }
\end{aligned}
$$

Fire from Heaven: The Life of an English Town

in the Seventeenth Century

Yale University Press, 1992

The Walter D. Love Prize for the best scholarly article of 1992 in any field of British Studies has been awarded to

$$
\begin{gathered}
\text { Judith M. Bennett } \\
\text { for her article }
\end{gathered}
$$

"Conviviality and Charity in Medieval and Early Modern England"

Past and Present, no. 134 (May 1992)

The NACBS Dissertation Year Fellowship for the 1993-94 academic year has been awarded to

Amy Froide

History Department, Duke University, for dissertation research in Britain on

"Single Women, Work, and Community in England, 1550-1750" 


\section{Joseph Chamberlain}

Entrepreneur in Politics

Peter T. Marsh

Joseph Chamberlain (1836-1914) was an industrialist who became "the first minister of the British Empire." This book is the first complete singlevolume biography of Chamberlain .

"Laced with passages of lasting interest." - The Economist $\$ 45.00$

\section{The Tory View of Landscape}

\section{Nigel Everett}

This book argues that the history of English landscape from about 1760 to 1820 reflected a struggle between proponents of a traditional, natural, Christian, organic-or tory-view of the landscape versus those who advocated the aggressive, privatizing, impersonal-or whig-tendencies of contemporary "improvement". $20 \mathrm{~b} / \mathrm{w}+5$ color illus. $\$ 40.00$

Published for the Paul Mellon Centre for Studies in British Art

\section{Pugin: A Gothic Passion}

Edited by Paul Atterbury and Clive Wainwright

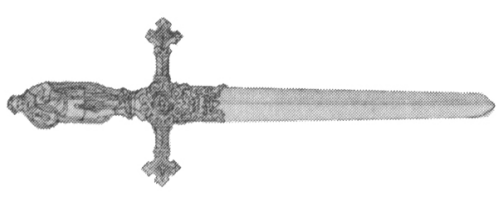

"A...charming volume on perhaps the most influential designer/architect in 19th-century Britain."-A. M. Homes, The Los Angeles Times Book Review 100 b/w +300 color $\$ 65.00$

\section{Yale University Press}

P.O. Box 209040, New Haven, CT 06520

\section{Literature and Revolution in England, 1640-1660}

\section{Nigel Smith}

The years of the British Civil War and Interregnum constituted a turning point not only in the political, social, and religious history of seventeenthcentury England but also in the use and meaning of English language and literature. This original book explores the effect that politics and literature had on each other during this period. $\$ 40.00$

\section{The Palladian Revival}

Lord Burlington, His Villa and Garden at Cheswick

\section{John Harris}

In this lavishly illustrated book, an eminent architectural historian focuses on the creation of Lord Burlington's famous "Villa by the Thames" in 1726, the touchstone of Neo-Palladian architecture.

$150 \mathrm{~b} / \mathrm{w}+75$ color illus. $\$ 50.00$

New in Paperbound

\section{The Stripping of the Altars}

Traditional Religion in England, 1400-1580

\section{Eamon Duffy}

This major revisionist account of the pre-Reformation church recreates how laypeople in 15th-century England experienced religion.

"Deeply imaginative, movingly written, and splendidly illustrated."-Maurice Keen, The New York Review of Books 143 illus. $\$ 18.00$

To order call 1-800-YUP-READ 


\section{The Best in British Studies}

\section{A Union for Empire}

Political Thought and the British Union of 1707

John Robertson, Editor

This volume of scholarly essays explores the ideas of union and empire current at the time of the Union between Scotland and England in 1707. It demonstrates for the first time the wider significance of the Union in Europe and throughout the English-speaking world.

Contributors: John Robertson, Stepben Pincus, Laurence Dickey, David Armitage, Roger L.

Emerson, Colin Kidd, Katberine R. Penovicb,

John W. Cairns, Jacqueline Hill, Ned Landsman, J. G. A. Pocock

Publisbed in assoctation witb the

Folger Institute, Wasbington, D.C.

43113-1 Hardback about $\$ 59.95$

\section{Tudor Political Culture \\ Dale Hoak, Editor}

The twelve interdisciplinary essays on the ideas, images and rituals of Tudor and early Stuart society open up new perspectives on the ideas, institutions and rituals of political society. Key aspects of Tudor political culture are explored, including royal iconography, funereal symbolism, parliamentary elections, political vocabularies, kinship and family at court and in the country, and the architecture of urban authority.

Contributors: Sir Geoffrey Elton, Dale Hoak, Thomas F Mayer, Retba M. Warnicke, John N. King, Robert Tittler, William Tigbe, J. F R. Day, Peter C. Herman, Norman Jones, David Dean, David Harris Sacks, Jobn Guy 40494-0 Hardback \$64.95

\section{Catholic and Reformed}

The Roman and Protestant Churches in English Protestant Thought, 1600-1640

\section{Anthony Milton}

Religious controversy was central to political conflict in the years leading up to the outbreak of the English Civil War. Catholic and Reformed analyzes the broad preconceptions that lay behind religious debate, offering an analysis of the nature of the English Church, and how this related to the Roman Catholic and Reformed Churches of the Continent. The book's conclusions explain the nature of English religious culture and its role in provoking the Civil War.

Cambridge Studies in Early Modern Britisb History

40141-0 Hardback \$79.95

\section{Men At Work}

Labourers and Building Craftsmen in the Towns of Northern England, $1450-1750$

\section{Donald Woodward}

This study redresses the North and South imbalance of much of the work in British economic and social history by focusing on the impact of the building trade. Using sources from local archives, the author addresses conditions of work in the building trades, levels of remuneration, gender differences in work, and relationships with employers.

Cambridge Studies in Population, Economy and Society in Past Time 26 47246-6 Hardback $\$ 59.95$

\section{The World of Rural Dissenters, 1520-1725 Margaret Spufford, Editor}

There has been dispute among social historians about whether only the more prosperous in village society were involved in religious practice. By examining the taxation records of sufficiently large groups of dissenters and church wardens, this book presents a factual solution.

Contributors: Margaret Spufford, Derek Plumb, Eric Carlson, Cbristopber Marsh, Tessa Watt, Michael Frearson, Nesta Evans, Peter Spufford, Bill Stevenson, Patrick Collinson 41061-4 Hardback $\$ 79.95$

\section{The Political Economy of Nationalisation in Britain 1920-50 \\ Robert Millward and John Singleton, Editors}

In this study of the causes of nationalization, experts in British industrial history analyze the public ownership debates. During the Labour governments of 194551 a number of important industries were taken into public ownership, and legislation was passed for the nationalization of the steel industry. It was argued that nationalization would lead to an improvement in the efficiency of these key sectors, on which the rest of British industry depended for inputs.

Contributors: Robert Millward, Jobn Singleton, David Greasley, Peter Lyth, Sue Bowden, Gerard Crompton, Jobn Wilson, David Edgerton, Jobn Hassan, Peter Howlett, Martin Cbick, Ruggiero Ranieri 45096-9 Hardback \$59.95 


\section{The Best in British Studies}

\section{Constructing a Competitive Order}

The Hidden History of

British Anti-Trust Policies

\section{Helen Mercer}

Mercer presents a new interpretation of the evolution of British competition legislation from 1900 to 1964 . She uses archival sources to give a detailed analysis of government-industry relations and shows how competition policies have been shaped by the strategies of powerful business interests. Throughout the book, she offers pointers to the likely outcome of business regulation in Britain in the future. 41292-7 Hardback about $\$ 59.95$

\section{The Early History of the Law of Bills and Notes \\ A Study of the Origins of Anglo-American Commercial Law James Stevens Rogers}

This study traces the history of the law of bills and notes in England from medieval times to the period in the late eighteenth and early nineteenth centuries when bills played a central role in the domestic and international financial system. Challenging traditional theories, it shows that the law of bills was developed within the common law system itself, in response to changing economic and business practices.

Cambridge Studies in Englisb Legal History 44212-5 Hardback $\$ 59.95$

\section{Fifteenth-Century Attitudes}

Perceptions of Society in

Late Medieval England

\section{Rosemary Horrox, Editor}

This fresh and invigorating look at late medieval English society focuses not on how people lived but on how they saw the world and their place in it. Alongside contributions on how different social groups saw themselves and were seen by others are more general discussions of key aspects of fifteenth-century life: attitudes to the rule of law, to the power of the ruler, to education, to honor and service, and finally to death.

Contributors: G. L. Harriss, Edward Powell, Kate Mertes, Rosemary Horrox, Michael J. Bennett, Peter Murray Jones, P. J. P. Goldberg. D. M. Palliser, Mark Bailey, Miri Rubin, Colin Ricbmond, Margaret Aston 40483-5 Hardback $\$ 54.95$
Prices, Food and Wages in Scotland, 1550-1780

\section{A. J. S. Gibson and T. C. Smout} Using the remarkable series of "fiars" prices for grains and other contemporary sources, this study of Scottish price history focuses, in particular, on the prices of grain, meal and animal products, and assesses how Scots laborers could survive in an economy that could pay only very low money wages. Their conclusions make a powerful contribution to the perennial debate on the standard of living of ordinary people prior to industrialization. 34656-8 Hardback $\$ 74.95$

\section{The Chief Governors}

The Rise and Fall of Reform

Government in Tudor Ireland, 1536-1588

\section{Ciaran Brady}

This book offers a fundamental critique of conventional views of sixteenth-century Irish history that have stressed the centrality of colonization and military confrontation. It argues that reform rather than conquest was the aim of Tudor policy-makers, but shows that the immense difficulties faced by the reformers in pursuing their objectives forced them to make administrative innovations that ultimately contradicted and undermined their original policy.

Cambridge Studies in Early Modern Britisb History

46176-6 Hardback $\$ 59.95$

\section{Sir Matthew Hale, 1609-1676 \\ Law, Religion and Natural Philosophy Alan Cromartie}

Sir Matthew Hale (1609-76) was both the best-known judge of the Commonwealth under Oliver Cromwell and Lord Chief Justice under King Charles II. His constitutional ideas are of interest both to lawyers and to historians of political thought; but he also wrote extensively on scientific and religious questions, in ways that illustrate the birth of early Enlightenment attitudes to both. This book surveys all aspects of Hale's work, and supplies fresh perspectives on revolutionary developments in science and religion, as well as politics.

Cambridge Studies in Early Modern Britisb History

45043-8 Hardback $\$ 59.95$ 


\section{The Best in British Studies}

\section{A Short History of Ireland Second Edition John O'Beirne Ranelagh \\ "A book wbich compresses the Irisb story from prebistory to post-Sunningdale with notable dexterity and justice of scale... attains a remarkably dispassionate detacbment of tone." \\ -The Times Educational Supplement}

First published in 1983, this revised and extended edition stresses the importance of the pre-Norman Gaelic "golden age," the conflicts during the violence of the Viking invasions, and the upheavals of the Tudor period as well as the later struggles for national identity and independence. 47548-1 Hardback \$64.95 46944-9 Paperback $\$ 16.95$

\section{Ireland from Independence to Occupation, 1641-1660} Jane $H$. Ohlmeyer, Editor

This interdisciplinary collection of essays examines how the tumultuous events of the 1640 s and 1650 s transformed the course of Ireland's intellectual, social, economic, military, tenurial and, of course, political history. The essays also seek to set Ireland in its wider European and British contexts. Contributors: Jane Oblmeyer, Nicbolas Canny, Scott Wheeler, Rolf Loeber, Geoffrey Parker, Micbelle O Riordan, Jobn Adamson, Raymond Gillespie, Kevin MacKenny, Phil Kilroy,

T. C. Barnard, Aidan Clarke

43479-3 Hardback \$59.95

\section{Hume: Political Essays David Hume Knud Haakonssen, Editor}

David Hume, one of the greatest English philosophers, was also an outstanding political and economic theorist and historian. His political essays reflect the entire range of his intellectual engagement with politics. Twenty-seven of the most important ones are presented in this fully annotated edition. Cambridge Texts in tbe History of Political Tbougbt

46093-X Hardback \$49.95

46639-3 Paperback $\$ 15.95$

Available in bookstores or from

\section{CAMBRIDGE UNIVERSITY PRESS}

40 West 20th St., N.Y., NY 10011-4211

Call toll-free $800-872-7423$

MasterCard/VISA accepted. Prices subject to change.

\section{Writing and the Rise of Finance Capital Satires of the Early Eighteenth Century Colin Nicholson}

In this original study, Nicholson reads familiar texts such as Gulliver's Travels, The Beggar's Opera and The Dunciad as "capital satires," responding to the social and political effects of the installation of capitalist financial institutions in London While they invested in stocks and shares, Swift, Pope and Gay conducted a campaign against the civic effects of new financial institutions. Conflict between these writers' inherited discourse of civic humanism and the transformations being undergone by their own society is shown to have had a profound effect on a number of key literary texts.

Cambridge Studies in Eigbteentb-Century Englisb Literature and Tbougbt 21

45323-2 Hardback $\$ 54.95$

\section{Keats and History}

Nicholas Roe, Editor

Thirteen essays address the historical dimensions of Keats's poems and letters, and open fresh perspectives on his achievement. Keats's writings are approached through politics, social history, feminism, economics, historiography, stylistics, aesthetics, and mathematical theory.

Contributors: Susan J. Wolfson, Martin Aske, John Barnard, Daniel P. Watkins, Kelvin Everest, Terence Allan Hoagwood, Micbael O'Netll, Vincent Newey, Nicholas Roe, Theresa M. Kelley, Nicola Trott, Jobn Kerrigan, Greg Kucich

44245-1 Hardback \$59.95

Now in a Canto edition... The British Isles

A History of Four Nations Hugh F. Kearney

Challenging traditional accounts of what constitutes national history, this unique account of the British Isles from pre-Roman times to the twentieth century is distinguished by its stress on the fact that English history forms only part of a broader "history of four nations." To ignore this wider dimension is to distort our view of the past and hinder our understanding of the present.

A Canto Book

48488-X Paperback $\$ 11.95$ 


\section{The International History Review}

Since 1979, The Review has been read in thirty-eight countries by scholars, students, and informed general readers. The Review is the only English-language quarterly devoted entirely to the history of international relations. With 224 pages per issue, The Review publishes articles, notes with documents, bibliographies, and reviews, on everything that affected, or was affected by, the relations between all states, throughout the world, throughout history, from Ancient Greece to the Gulf War. At least seventy books are reviewed in each issue by scholars from twenty-five countries.

Recent contributors include Paul Kennedy, Fergus Millar, Jonathan Israel, Paul W. Schroeder, Martin Kitchen, A. P. Thornton, Alexander DeConde, Enno E. Kraehe, Gerhard L. Weinberg, P. J. Marshall, Anna M. Cienciala, Roderic H. Davison, Norman Rich, R. J. W. Evans, G. V. Scammell, Barbara Jelavich, Holger H. Herwig, L. Carl Brown.

Recent special issues on the Decline of Great Britain, the Atlantic Empires in the Eighteenth Century, Sea Power, British Colonial Societies in the Age of Revolution, Wellington at War, and Central European Entanglements. All back issues available at $\$ 15$ (US) each.

EDITOR: Edward Ingram

Professor of Imperial History at Simon Fraser University

\section{Editorial Advisory BoARD}

R. J. B. Bosworth (Western Australia) Roger Owen (Harvard)

P. A. Cartledge (Cambridge) Geoffrey Parker (Yale)

H. E. J. Cowdrey (Oxford) Jürgen Rohwer (Stuttgart)

Bruce Cumings (Northwestern) Denis Smyth (Toronto)

Holger H. Herwig (Calgary) Niels Steensgaard (Copenhagen)

Norman Hillmer (Carleton) Janice Stein (Toronto)

Michael H. Hunt (North Carolina) Nicholas Tarling (Auckland)

A. S. Kanya-Forstner (York) William R. Thompson (Indiana)

John A. Lynn (Illinois)

Alan S. Milward (London)

André Wink (Wisconsin-Madison)

Robert J. Young (Winnipeg)

Gerhard L. Weinberg (North Carolina)

Institutions: \$92 (US); Individuals: \$30 (US).

For details, please write:

The International History Review

Simon Fraser University

Burnaby, British Columbia

CANADA V5A IS6

Tel: 604-29I-356I; Fax: 604-29I-3429

E-Mail: Intl_Hist_Rev@sfu.ca

A Free Sample Issue Is Available to Libraries Upon Request. 


\section{GREAT BRITAIN}

\section{Selected Poems}

MATTHEW ARNOLD

Edited by Timothy Peltason

A selection of Arnold's best and most memorable poems, including such major works as "Dover Beach" and "Thrysis" and the full texts of "Empedocles on Etna" and "Tristram and Iseult." $256 \mathrm{pp}$.

A Penguin Classic

0-14-042376-1

$\$ 9.95$

\section{Complete Short Fiction OSCAR WILDE}

Edited with an

Introduction by Ian Small

Contains the complete texts of The Happy Prince and Other Tales, A House of Pomegranates, Lord Arthur Savile's Crime and Other Stories, six "Poems in Prose," and "The Portrait of Mr. W. H." 336 pp.

\section{A Penguin Classic \\ 0-14-043423-2 \\ $\$ 9.95$ \\ Available May 1995}

\section{The Modern British Novel MALCOLM BRADBURY}

This major work of literary history covers a century of British fiction, ranging from the works of Thomas Hardy to Angela Carter, as well as the genre of the English novel itself. 304 pp.

A Penguin paperback original

0-14-023098-X

$\$ 13.95$
The Eye in the Door

PAT BARKER

Winner of the Guardian Fiction Prize. "Impressive...illuminating with compassion and insight the toll the war exacted from Britain's combatants and their world."-New York Times Book Review. 288 pp.

A William Abrahams/Plume paperback

0-452-27272-6

$\$ 10.95$

\section{Small World}

DAVID LODGE

The second of Lodge's trilogy of academic satires is set during academic conference season, where the English professors are on the loose, competing, coupling, and occasionally attending meetings. $400 \mathrm{pp}$.

A Penguin paperback

0-14-024486-7

$\$ 10.95$

Available May 1995

\section{Kidnapped}

ROBERT LOUIS STEVENSON

Edited with an

Introduction by Donald McFarlan

Set in the aftermath of the Jacobite Revolution of 1745 , Kidnapped is a swashbuckling adventure tale of family treachery, abduction, and murder. With 2 maps. 272 pp.

A Penguin Classic

0-14-043401-1 $\$ 9.95$

For a free History catalog, please call (212) 366-2372 


\section{The Penguin Social}

\section{History of Britain 1870-1914 JOSE HARRIS}

An essential, one-volume account of Great Britain during one of the most contradictory periods in history, taking into account the attitudes toward poverty, work, religion, social reform and theory, family life, and sexuality that marked the era. 304 pp.

A Penguin paperback

0-14-012548-5

$\$ 12.95$

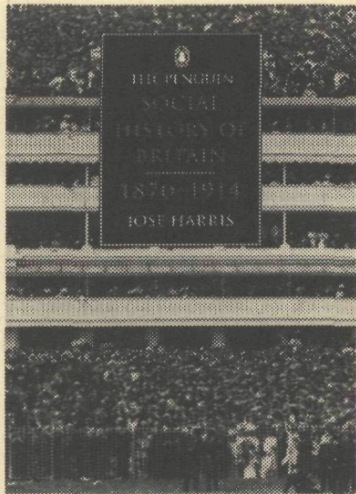

\section{The Economic}

Consequences of the Peace JOHN MAYNARD KEYNES

Introduction by Robert Lekachman

First published in 1919, Keynes' brilliant and prescient analysis of the economic effects of the Treaty of Versailles has been called "the most important economic document on World War I and its aftermath."-John Kenneth Galbraith. 336 pp.

A Penguin Twentieth-Century Classic

0-14-018805-3

$\$ 12.95$

\section{The Adventures}

\section{of John Wetherell}

Edited and with an

\section{Introduction by C. S. Forester}

The lively diary of a British seaman who was impressed into the Royal Navy to fight the French at the beginning of the nineteenth century. $276 \mathrm{pp}$.

A Michael Joseph paperback 0-7181-3844-9

$\$ 11.95$

Available June 1995

\section{An Ensign in}

the Peninsular War

The Letters of John Aitchison

Edited by W. F. K. Thompson

A revealing firsthand, account of the Peninsular War, told through the letters and diaries of a young ensign in the British 3rd Foot Guards. With 18 maps. $352 \mathrm{pp}$.

A Michael Joseph paperback

0-7181-3840-6

$\$ 12.95$

Available June 1995

\section{Wellington's War}

His Peninsular Dispatches JULIAN RATHBONE

A vivid look at the Peninsular War the man who did more to direct its outcome than any other-Arthur Wellesley, the Duke of -Wellington. With 13 black-and-white drawings and 25 maps. 352 pp.

A Michael Joseph paperback

0-7181-3841-4

$\$ 14.95$

Available June 1995

\section{P. E N G I N U S A}




\section{UNIVERSITY OF CAMBRIDGE .}

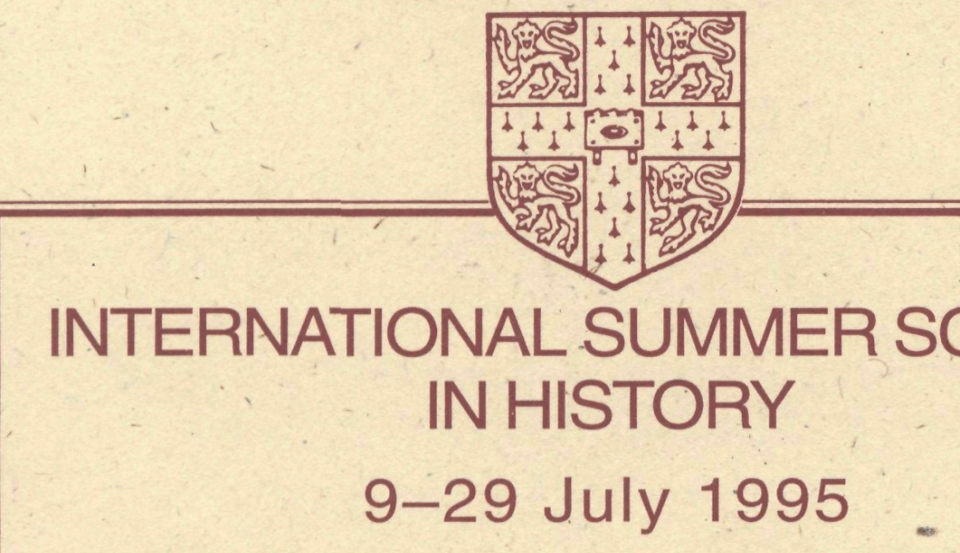

for students and teachers of British and European history

plenary sessions by eminent historians, with daily specialized seminars

for full details, contact:

University of Cambridge,

International Programmes,

Madingley Hall, Madingley,

Cambridge CB3 8AQ, England

Tel: $(U K=44) 1954210636$

Fax: $(U K=44) 195421.0677$

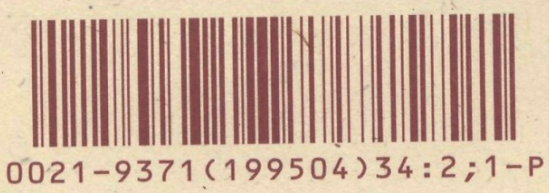

